\title{
Development of a Learning Ecosystem Using Digital Knowledge Engineering Through MOOCs Knowledge Repository System
}

\author{
https://doi.org/10.3991/ijep.v11i1.15011 \\ Nattaphol Thanachawengsakul ${ }^{(凶)}$ \\ Chandrakasem Rajabhat University, Bangkok, Thailand \\ nattaphol.techandra.ac.th \\ Panita Wannapiroon \\ King Mongkut University of Technology North Bangkok, Bangkok, Thailand
}

\begin{abstract}
This paper presents the development of a learning ecosystem using digital knowledge engineering through a MOOCs knowledge repository system. This system comprises four parts: (1) Stakeholders, including instructors and learners; (2) A digital knowledge engineering learning process that describes the roles of instructors and learners, learning activities, and instructional tools; (3) A MOOCs knowledge repository system, which is the software developed to enhance digital entrepreneurs' competencies; and (4) Digital entrepreneurs' competencies, which describe learning outcomes using the digital knowledge engineering learning process. The suitability of the learning ecosystem was assessed by twelve experts possessing at least three years of related experience. They judged its suitability to be at the highest level. This study can be used to support further development of the MOOCs knowledge repository system assess digital entrepreneurs' competencies according to digital knowledge engineering learning process.
\end{abstract}

Keywords - Learning Ecosystem, Digital Knowledge Engineering, MOOCs Knowledge Repository, Digital Entrepreneurs' Competencies

\section{Introduction}

Advancements in technology, communication, and transportation have brought significant changes in global economic and industrial performance with regard to the expansion of economic growth, information sharing, product exchange and cross-cultural exchange. Additionally, changes in consumer behavior worldwide has been an important factor in establishing a vision and strategies for national development [1]. For instance, Thailand has the ultimate goal of using structural reforms to extricate the country from a middle-income trap by developing it into an innovation economy through the implementation of a New Growth Engine Policy. Such a policy will be important in accelerating Thailand's future growth. It is focused on 10 targeted industries; five existing high potential industries and an additional five new industries. To further boost its 
competitiveness, Thailand must produce highly skilled personnel to develop the manufacturing workforce of the future [2].

Manpower and personnel development for operational readiness arising from rapid changes in economy, industry and technology, several organizations implemented knowledge management system as a tool for gathering collective knowledge of human expertise through their abilities as well as information retrieval and knowledge distribution. Knowledge management system can help organizations in creating the superior value of intellectual capital by supporting the process of decision making with respect to products and services [3]. Knowledge management tool was later developed for creating innovative knowledge and knowledge storage through systematic process using digital technologies e.g., knowledge repositories system and MOOCs [4-5]. The development process involved the application of digital knowledge engineering in organizations and educational institutions to facilitate collaboration between employees/learners and teachers/experts having direct experience regarding knowledge creation, dissemination and distribution and sharing for best practices. The system can help businesses define problems and seek solutions comprising six steps [6-8]:

1. Knowledge creation: The process involved construction of useful knowledge used in educational contexts as well as career and organizations' operations whereby everyone works collaboratively in creating knowledge through digital technology.

2. Knowledge storage: It referred to knowledge storage, maintenance, improvement and check derived from knowledge creation process with the use of database management system through digital technology.

3. Knowledge acquisition: It referred to the process of data searching/retrieval where things were deposited in database management system and the results were shown in digital technology.

4. Knowledge access: It referred to learning in respect of knowledge that was derived from knowledge acquisition process through digital technology.

5. Knowledge sharing: This process involved knowledge transfer and sharing as well as providing consultation/guidance, answering queries and expressing opinions through digital technology.

6. Knowledge application: It referred to knowledge application in problem solving and various organizational practices. If knowledge generation occurred or there was a new way of working after the process of knowledge application, new knowledge can be reverted to using in the first step.

MOOCs (Massive Open Online Courses) is an online educational management system that uses computer and internet technology applications to develop online courses enabling people across the world to participate in online education (free of charge and without any limit on attendance). MOOCs is a lifelong learning space [9] consistent with Demand New S-Curve B.E. 2563-2567 (2020-2023) [2] Manpower Development in accordance with Industry 4.0 Policy or the Five-year New S-curve Plan. The Third Strategy aims to enhance lifelong learning and future skills by establishing a training system for the reskill/upskill of personnel; for example, by supporting a credit bank system, developing micro credential short courses or nano degrees, providing financial aid for reskill/upskill, and developing and extending the results of MOOCs educational 
system. The Fifth Strategy is associated with higher education reforms in Thailand, namely university repositioning in accordance with the potential for desirable consequences and developing universities into an entrepreneurial business incubator to solve community problems. The strategy encompasses the commercial use of research studies, including the development of basic structures and training programs, to strengthen skills and transform low-skilled workers into high-skilled workers [10]. It also encourages higher education institutions to reduce paper consumption and use digital technology for checking, recording, and managing digital footprint data [11].

Both technological advancement and the importance of innovation have brought radical changes in industrial sectors. These have equipped personnel with professional standards and enabled people to develop the knowledge required to boost national competitiveness in the 4.0 era. The researchers in the current study proposed the development of a learning ecosystem using digital knowledge engineering through a MOOCs knowledge repository system. This was achieved by acquiring knowledge from experts with a high-level of expertise and direct experience in sharing information in accordance with the digital knowledge engineering process. This will help to establish a learning community and promote lifelong learning and will support the re-skilling or upskilling of Thai entrepreneurs to ensure they become digitally efficient.

\section{Research Objectives}

1. Learning ecosystem development using digital knowledge engineering through MOOCs knowledge repository system

2. Learning ecosystem assessment using digital knowledge engineering through MOOCs knowledge repository system

\section{Research Methodology}

This research comprised two stages:

\subsection{Development of a learning ecosystem using digital knowledge engineering through a MOOCs knowledge repository system}

This was based upon the information gathered from documents, textbooks, and academic journals. It drew upon the concepts and theories of relevant research papers from domestic and international sources and the analysis and synthesis of data using content analysis.

\subsection{Assessment of the learning ecosystem using digital knowledge engineering through a MOOCs knowledge repository system}

Assessment of the learning ecosystem through the use of a questionnaire checklist (five rating scales) completed by a purposive sample of twelve experts with at least 
three years of related experience. The process of data collection was divided into 4 parts: knowledge repository management, learning management, MOOCs system, and digital entrepreneurs' competencies, with three experts performing the assessment in each of the given sessions.

As previously mentioned, the research methodology was illustrated in Figure 1:

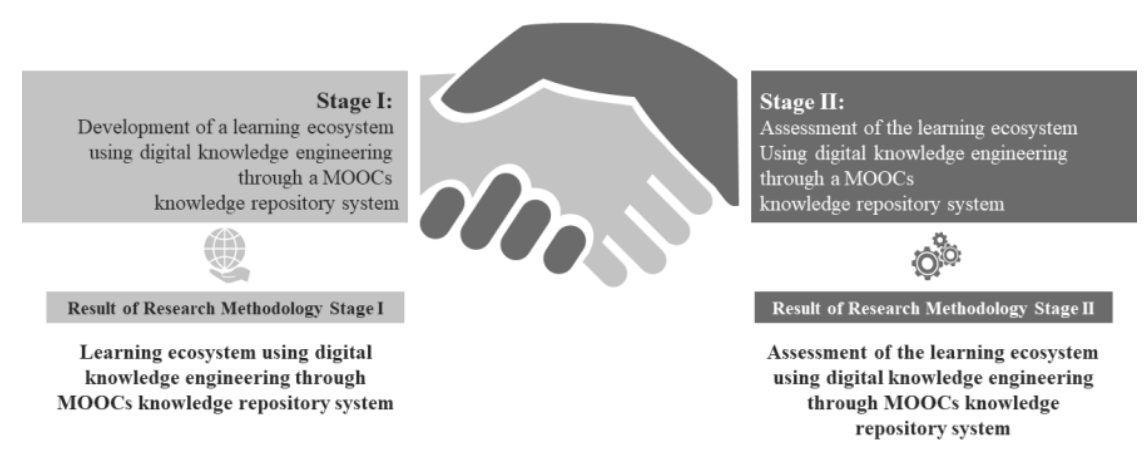

Fig. 1. Research Methodology

\section{$4 \quad$ Research Results and Discussion}

\subsection{Results of learning ecosystem development using digital knowledge engineering through a MOOCs knowledge repository}

The learning ecosystem consists of 4 parts: Stakeholders; a digital knowledge engineering learning process describing the roles of instructors/learners, learning activities, and instructional tools; MOOCs knowledge repository system; and digital entrepreneurs' competencies in describing the learning outcomes using the learning ecosystem. This is based on a Conceptual Framework for the Development of a MOOCs-Based Knowledge Repository to Enhance Digital Entrepreneurs' Competencies [12], as illustrated in Figure 2: 
Paper-Development of a Learning Ecosystem Using Digital Knowledge Engineering Through MOOCs...

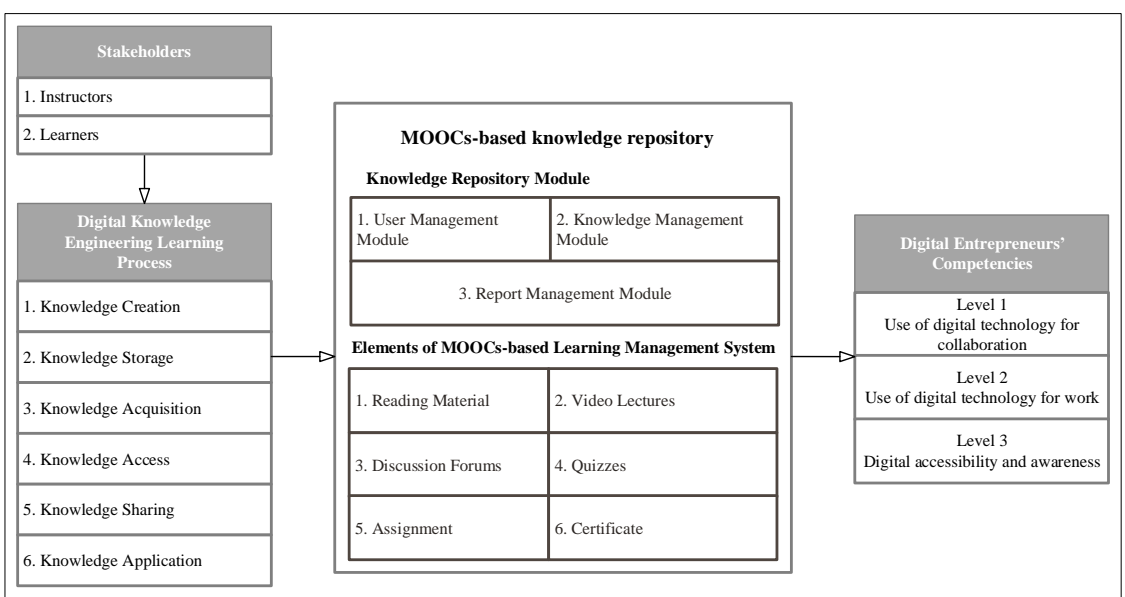

Fig. 2. Conceptual Framework for the Development of a MOOCs-Based Knowledge Repository to Enhance Digital Entrepreneurs' Competencies [12]

Based on the conceptual framework shown in Figure 2, the process of developing the learning ecosystem was conducted as shown in Figure 3:

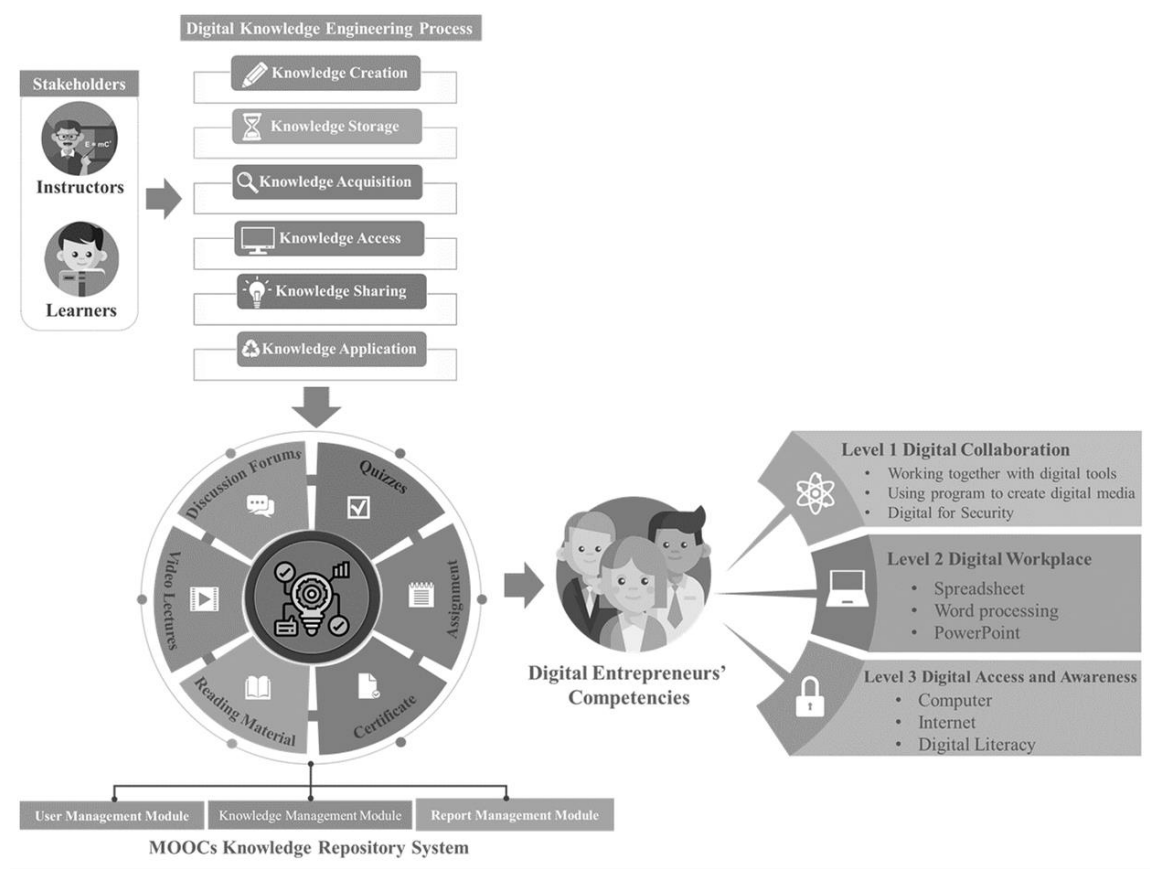

Fig. 3. Learning Ecosystem Using Digital Knowledge Engineering through MOOCs Knowledge Repository System 
The learning ecosystem was divided into four parts:

1. Two groups of stakeholders:

- Instructors: These transfer knowledge to others and support learning in higher education under the Higher Education Commission, Ministry of Higher Education, Science, Research and Innovation.

- Learners: Entrepreneurs operating small and medium enterprises in Bangkok who participated in research studies and learned about content relating to the application of digital technology for careers to promote digital entrepreneurship.

2. Digital Knowledge Engineering Learning Process: A learning process established by instructors and experts with a high-level of expertise and direct experience. Their aim was to make the learning process accessible to students so that they can conduct their own studies, discover information, share knowledge [13], and systematically reskill and upskill their abilities. The details of this process are as follows:

- Knowledge Creation: This involves the creation of digital entrepreneurship related reading material by instructors. By generating new ideas from the final learning digital knowledge engineering process, learners can mutually create relevant learning content. The process is illustrated in Table 1:

Table 1. Knowledge Creation

\begin{tabular}{|l|l|}
\hline Roles of Instructor & - Introduction \\
& - Learning objectives \\
& - Knowledge creation involving the application of digital \\
& technology for careers to promote digital entrepreneurship \\
\hline Roles of Learners & - Responding to questions regarding course related content \\
& - Collaborative knowledge construction involving the application of digital technol- \\
& ogy for careers to promote digital entrepreneurship \\
\hline Learning Activities & - Questioning regarding course related content \\
& - Responding to questions regarding course related content \\
& - Knowledge sharing \\
& - Knowledge creation \\
\hline Instructional Tools & - MOOCs knowledge repository system \\
& - Knowledge Management Module \\
\hline
\end{tabular}

The Knowledge Creation as show in Table 1 was illustrated in Figure 4. 


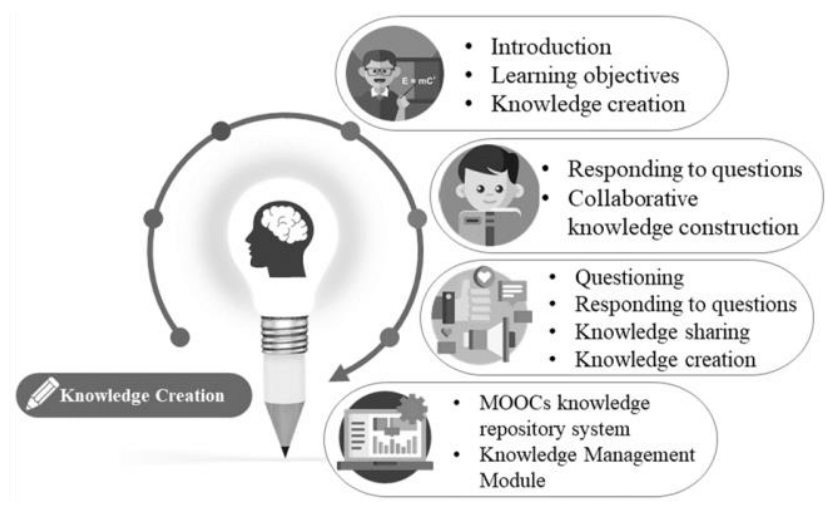

Fig. 4. Knowledge Creation

- Knowledge Storage: This process involves the recording and storage of digital entrepreneurship related reading material data in a database management system that forms part of the knowledge repository system. The process is illustrated in Table 2:

Table 2. Knowledge Storage

\begin{tabular}{|l|l|}
\hline Roles of Instructor & $\begin{array}{l}\text { Recording and storage of reading material data regarding the application of digital } \\
\text { technology for careers to promote digital entrepreneurship }\end{array}$ \\
\hline Roles of Learners & $\begin{array}{l}\text { Recording and storage of reading material knowledge regarding the application of } \\
\text { digital technology for careers to promote digital entrepreneurship }\end{array}$ \\
\hline Learning Activities & Recording and storage of knowledge in Database Management System \\
\hline Instructional Tools & $\begin{array}{l}\text { - MOOCs knowledge repository system } \\
\text { - Knowledge Management Module }\end{array}$ \\
\hline
\end{tabular}

The Knowledge Storage as show in Table 2 was illustrated in Figure 5.

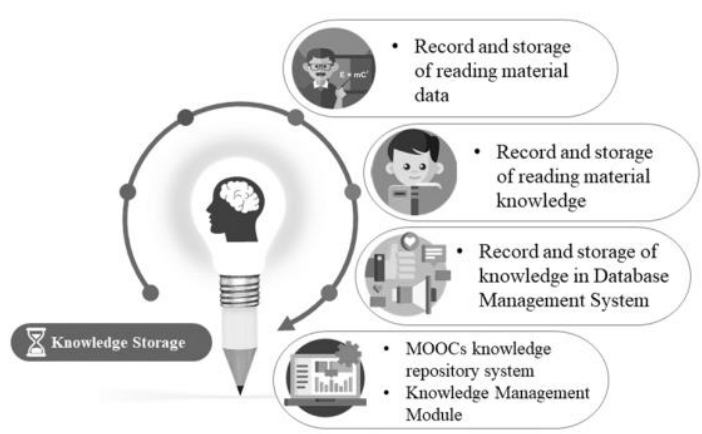

Fig. 5. Knowledge Storage

- Knowledge Acquisition: This process involves searching/retrieval of data concerning digital entrepreneurship from a knowledge repository where data are deposited for storage or safekeeping in a database management system. The search results are displayed for different types of content. The process is illustrated in Table 3: 
Table 3. Knowledge Acquisition

\begin{tabular}{|l|l|}
\hline Roles of Instructor & $\begin{array}{l}\text { Enabling learners to search and retrieve information regarding the application of } \\
\text { digital technology for careers to promote digital entrepreneurship }\end{array}$ \\
\hline Roles of Learners & $\begin{array}{l}\text { Searching and retrieving information recorded and stored in the database regarding the } \\
\text { application of digital technology for careers to promote digital entrepreneurship }\end{array}$ \\
\hline Learning Activities & $\begin{array}{l}\text { Comprehensive searching of information on digital entrepreneurship recorded and } \\
\text { stored in the database }\end{array}$ \\
\hline Instructional Tools & $\begin{array}{l}\text { - MOOCs knowledge repository system } \\
\text { - Knowledge Management Module }\end{array}$ \\
\hline
\end{tabular}

The Knowledge Acquisition as show in Table 3 was illustrated in Figure 6.

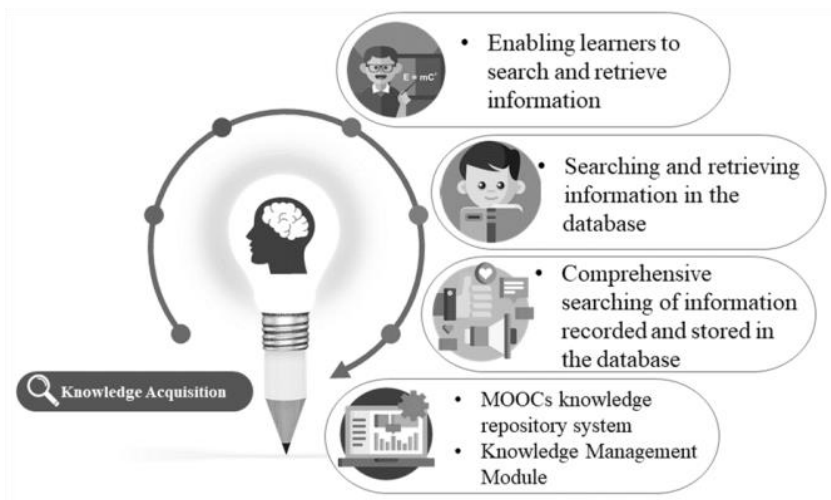

Fig. 6. Knowledge Acquisition

- Knowledge Access: This process involves developing digital entrepreneurship related reading material through the MOOCs learning management system, as illustrated in Table 4:

Table 4. Knowledge Access

\begin{tabular}{|l|l|}
\hline Roles of Instructor & $\begin{array}{l}\text { - Engaging learners in learning about the application of digital technology for } \\
\text { careers to promote digital entrepreneurship } \\
\text { - Monitoring student behavior }\end{array}$ \\
\hline Roles of Learners & $\begin{array}{l}\text { Taking an active role in learning about the application of digital technology for careers to } \\
\text { promote digital entrepreneurship having obtained information from the previous process }\end{array}$ \\
\hline Learning Activities & $\begin{array}{l}\text { Comprehensive learning regarding digital entrepreneurship having obtained } \\
\text { information from the previous process }\end{array}$ \\
\hline Instructional Tools & $\begin{array}{l}\text { - MOOCs knowledge repository system } \\
\text { - Knowledge Management Module }\end{array}$ \\
\hline
\end{tabular}

The Knowledge Access as show in Table 4 was illustrated in Figure 7. 


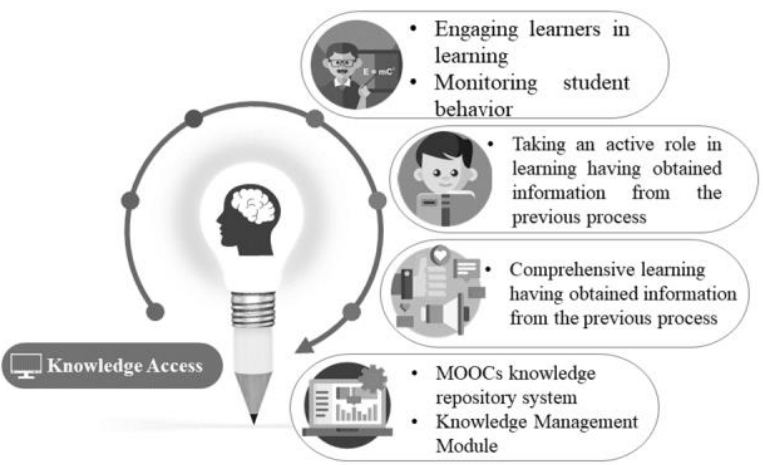

Fig. 7. Knowledge Access

- Knowledge Sharing: This process involves knowledge sharing and task fulfillment among students in connection with digital entrepreneurship learning through the MOOCs learning management system to improve their skills. This process is shown in Table 5:

Table 5. Knowledge Sharing

\begin{tabular}{|l|l|}
\hline Roles of Instructor & $\begin{array}{l}\text { - Monitoring student behavior } \\
\text { - Giving students guidance through expertise in theory and knowledge regarding the application of } \\
\text { digital technology for careers } \\
\text { - Answering students' queries }\end{array}$ \\
\hline Roles of Learners & $\begin{array}{l}\text { - Participation in learning activity } \\
\text { - Knowledge sharing regarding the application of digital technology for careers to } \\
\text { promote digital entrepreneurship }\end{array}$ \\
\hline Learning Activities & $\begin{array}{l}\text { Practice-based learning regarding the application of digital technology for careers } \\
\text { to promote digital entrepreneurship }\end{array}$ \\
\hline Instructional Tools & $\begin{array}{l}\text { - MOOCs knowledge repository system } \\
\text { - Knowledge Management Module }\end{array}$ \\
\hline
\end{tabular}

The Knowledge Sharing as show in Table 5 was illustrated in Figure 8.

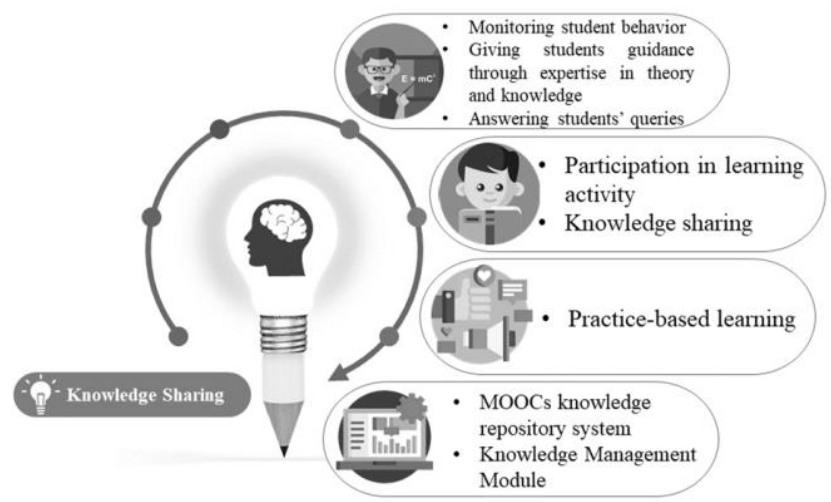

Fig. 8. Knowledge Sharing 
- Knowledge Application: This process comprises best practice digital entrepreneurship related knowledge management derived from the first-fifth stage learning processes followed by testing. This yields positive outcomes regarding effective problem solving, as illustrated in Table 6:

Table 6. Knowledge Application

\begin{tabular}{|l|l|}
\hline Roles of Instructor & Assessing learning achievement through a knowledge test and learning in practice \\
\hline Roles of Learners & $\begin{array}{l}\text { Knowledge test on the application of digital technology for careers to promote digital } \\
\text { entre-preneurship }\end{array}$ \\
\hline Learning Activities & $\begin{array}{l}\text { - Learning achievement assessment } \\
\text { - Project assessment } \\
\text { - Knowledge sharing activity }\end{array}$ \\
\hline Instructional Tools & $\begin{array}{l}\text { - MOOCs knowledge repository system } \\
\text { - Knowledge management module } \\
\text { - Report Management System }\end{array}$ \\
\hline
\end{tabular}

The Knowledge Application as show in Table 6 was illustrated in Figure 9.

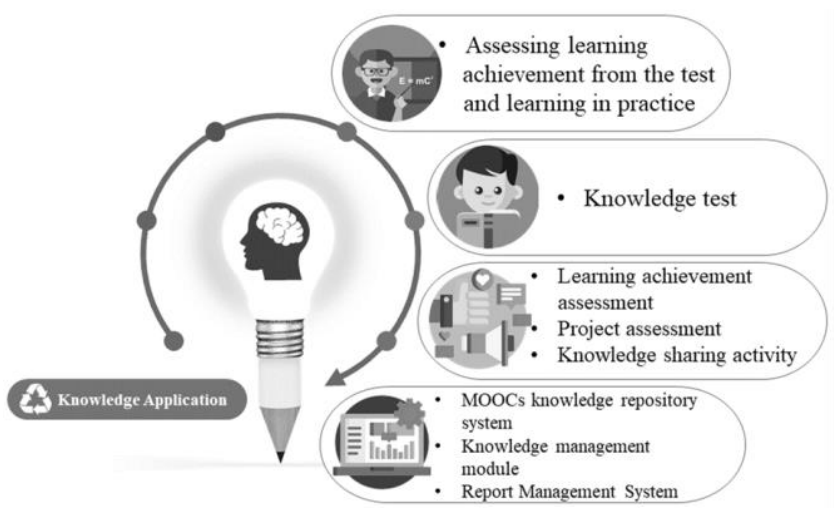

Fig. 9. Knowledge Application

3. MOOCs Knowledge Repository System: The MOOCs Knowledge Repository System is a form of software designed to facilitate effective collaborative learning between instructors and learners. It is based on a digital knowledge engineering learning process used to develop learners' competencies regarding digital entrepreneurship. The system is divided into two parts:

The Knowledge repository module consists of three parts, as illustrated in Table 7. 
Table 7. Knowledge Repository Module

\begin{tabular}{|l|l|}
\hline Module of Knowledge Repository & \multicolumn{1}{c|}{ Function } \\
\hline 1. User Management Module & $\begin{array}{l}\text { Subsystem used for user data management, including adding, editing, } \\
\text { deleting, and searching as well as configuring user access control } \\
\text { and permissions }\end{array}$ \\
\hline 2. Knowledge Management Module & $\begin{array}{l}\text { Subsystem used for digital entrepreneurship related knowledge manage- } \\
\text { ment, including adding, editing, } \\
\text { deleting, and searching combined with knowledge } \\
\text { management in accordance with the digital knowledge engineering } \\
\text { learning process }\end{array}$ \\
\hline 3. Report Management Module & $\begin{array}{l}\text { Subsystem used for producing and reporting data on PDF files; for ex- } \\
\text { ample, learners' achievement reports }\end{array}$ \\
\hline
\end{tabular}

- Elements of the MOOCs-based learning management system consists of five sections, as illustrated in Table 8:

Table 8. Elements of MOOCs-based Learning Management System

\begin{tabular}{|l|l|}
\hline \multicolumn{1}{|c|}{ Element } & \multicolumn{1}{c|}{ Function } \\
\hline 1. Reading Material & $\begin{array}{l}\text { Tool with a helpful text-based mode used for the management of } \\
\text { digital entrepreneurship related contents as well as other useful } \\
\text { information that supports learning. }\end{array}$ \\
\hline 2. Video Lectures & $\begin{array}{l}\text { Digital entrepreneurship related content management tool with video-based learn- } \\
\text { ing carried out in MOOCs. }\end{array}$ \\
\hline 3. Discussion Forums & $\begin{array}{l}\text { Text-based communication tool facilitating communication between teachers and } \\
\text { learners or among learners }\end{array}$ \\
\hline 4. Quizzes & $\begin{array}{l}\text { Tool for creating quizzes used for knowledge testing and assessing } \\
\text { digital entrepreneurship attributes }\end{array}$ \\
\hline 5. Assignment & $\begin{array}{l}\text { Tool providing assignment instructions for developing learners' } \\
\text { digital entrepreneurship skills based on practical learning situations }\end{array}$ \\
\hline 6. Certificate & $\begin{array}{l}\text { Certificate in PDF format issued to those who enrolled on a course and completed } \\
\text { all assignments and quizzes relating to digital } \\
\text { entrepreneurship }\end{array}$ \\
\hline
\end{tabular}

4. Digital Entrepreneurs' Competencies: Learning achievement based on the digital knowledge engineering learning process consisted of three parts: 1. knowledge, 2. skills, and 3. attributes (KSA Process). Learning content is related to the application of digital technology for careers to enhance digital entrepreneurs' competencies. This is divided into the three levels shown in Table 9:

Table 9. Digital Entrepreneurs' Competencies

\begin{tabular}{|l|l|}
\hline \multicolumn{1}{|c|}{ Level } & \multicolumn{1}{|c|}{ Learning Achievement } \\
\hline Level 1: Use of digital technology for collaboration & $\begin{array}{l}\text { 1. Online collaboration } \\
\text { 2. Digital media program } \\
\text { 3. Digital literacy }\end{array}$ \\
\hline Level 2: Use of digital technology for work & $\begin{array}{l}\text { 1. MS Excel } \\
\text { 2. MS Word } \\
\text { 3. MS PowerPoint }\end{array}$ \\
\hline Level 3: Digital accessibility and awareness & $\begin{array}{l}\text { 1. Computer usage } \\
\text { 2. Internet usage } \\
\text { 3. Digital literacy }\end{array}$ \\
\hline
\end{tabular}


4.2 Assessment of learning ecosystem using digital knowledge engineering through the MOOCs knowledge repository system

Table 10. Overall results regarding the assessment of the learning ecosystem

\begin{tabular}{|l|c|c|c|}
\hline \multicolumn{1}{|c|}{ Assessment issues } & \multicolumn{3}{c|}{ Level of Opinions } \\
\cline { 2 - 4 } & Mean & S.D. & Rating Scales \\
\hline 1. Stakeholders & 4.75 & 0.53 & Highest \\
2. Digital Knowledge Engineering Learning Process & 4.72 & 0.45 & Highest \\
3. MOOCs Knowledge Repository & 4.78 & 0.44 & Highest \\
4. Digital Entrepreneurs' Competencies & 4.89 & 0.32 & Highest \\
\hline \multicolumn{1}{|c|}{ Combined Mean } & $\mathbf{4 . 7 8}$ & $\mathbf{0 . 4 4}$ & Highest \\
\hline
\end{tabular}

As shown in Table 10, the suitability of the learning ecosystem was judged to be at the highest level $($ Mean $=4.78$, S.D. $=0.44)$. When the separate sections were arranged in descending order, digital entrepreneurs' competencies were at the highest level $($ Mean $=4.89$, S.D. $=0.32$ ) followed by MOOCs Knowledge Repository (Mean $=4.78$, S.D. $=0.44)$ and stakeholders $($ Mean $=4.75$, S.D. $=0.53)$, respectively.

\section{Conclusion}

Assessment by twelve experts of the learning ecosystem developed using digital knowledge engineering through the MOOCs knowledge repository system showed that it was deemed highly suitable. In terms of standard deviation, data distribution was low (less than 1.0) and consistent with experts' opinions. Moreover, the score results were arranged in the same group; thus, this study can be applied to the future development of a MOOCs knowledge repository system to enhance digital entrepreneurs' competencies in relation to knowledge, skills, and attitudes [14]. This is consistent with the concepts of Farquhar [15] Anupan, A., Nilsook, P., and Wannapiroon, P. [16], and Thanachawengsakul, N., Wannapiroon, P., and Nilsook. P. [17] "knowledge engineering process can be applied to learning and teaching management in educational institutions alongside digital technology and instructional tool [18] engaging learners in online collaboration activities through e-learning system and MOOCs learning system with its resources and elements helping learners to develop their learning progress", which is consistent with Gamage Perera and Fernando's concept of [19] and Hanif, A., Siddiqi, A, F., and Jalil, Z. [20] "Freedom to learn". This means learners can conduct their own studies through videos, self-assessment, teamwork and can do so free of charge and without any limit on attendance as they can access the course content from any location at any time. Leaners who complete MOOCs will be awarded a certificate confirming the completion of their studies.

This research paper can be used for further development regarding design of system architecture showing the elements and functions of the system so as to develop MOOCs knowledge repository system. Moreover, the developed system was tried out to assess digital entrepreneurs' competencies according to digital knowledge engineering learning process. 


\section{Acknowledgement}

I would like to express my sincere gratitude to Chandrakasem Rajabhat University for your generous offer of research funding under Award No. 2/2562, Fiscal Year 2019, and appreciate for the owners of research articles, documentary, textbooks, and all sources of information. Without their valuable opinions and ideas, the research would not have been accomplished.

\section{$7 \quad$ References}

[1] Ministry of Industry. (2016). Strategy for Industrial Development of Thailand 4.0 for 20 years (2017-2036). Bangkok: Ministry of Industry.

[2] Office of National Higher Education Science Research and Innovation Policy Council. (2020). Demand for Highly-Skilled Workers in the 10 targeted industries New S-Curve) and Manpower Development Policy (2520-2524). Bangkok: Ministry of Higher Education, Science, Research and Innovation.

[3] Thanalerdsopit, P., and Pongwiritthon, R. (2015). Knowledge Management for Research in Higher Education: A Case Study Rajamangala University of Technology Lanna. FEU Academic Review, 9(2-4): 63-75.

[4] Training Industry. (2019). [Online]. Knowledge Repositories. [cited 6 July 2019]. Available form: https://trainingindustry.com/wiki/content-development/knowledge-repositories/

[5] Thai MOOC. (2020). [Online]. Thai MOOC Platform. [cited 13 May 2020]. Available form: https://lms.thaimooc.org/

[6] Thanachawengsakul, T., Wannapiroon, P., and Nilsook, P. (2018). Digital Knowledge Engineering-based Environment for Developing Software Engineering Technical Skills. Journal of Industrial Education, 17(3): 230-237.

[7] Distanont, A. (2016). Knowledge Capture in Weaning Process. Suan Dusit Graduate School Academic Journal, 12(2): 201-218.

[8] Center of Excellence for Unified Knowledge and Language Engineering. (2019). [Online]. Research for Knowledge and Language Engineering. [cited 6 July 2019]. Available form: https://www.nectec.or.th/research/research-support/uknowcenter.html

[9] Chaimin, C. (2019). MOOC: Life Long Learning in the $21^{\text {st }}$ Century. Journal of Humanities and Social Sciences (CMRU), 1(1): 46-70.

[10] Royal Thai Embassy Washington D.C. (2020). [Online]. Thailand 4.0. [cited 1 April 2020]. Available from: URL. http://thaiembdc.org/thailand-4-0-2/

[11] Songsom, N., and Nilsook, P., and Wannapiroon, P., etc. (2020). System Design of a Student Relationship Management System Using the Internet of Things to Collect the Digital Footprint. International Journal of Information and Education Technology, 10(3): 222-226. doi: 10.18178/ijiet.2020.10.3.1367

[12] Thanachawengsakul, N. (2020). A Conceptual Framework for the Development of a MOOCs-Based Knowledge Repository to Enhance Digital Entrepreneurs' Competencies. International Journal of Information and Education Technology, 10(5): 346-350. https://doi. org/10.18178/ijiet.2020.10.5.1387

[13] Thanachawengsakul, T., Wannapiroon, P., and Nilsook, P. (2018). How a digital knowledge engineering learning process enhance technical skills in software engineering. World Transactions on Engineering and Technology Education, 16(3): 312-316. 
[14] Komarkova, A., Gagliardi, D., Conrads, J., and Collado, A. (2015). Entrepreneurship Competence: An overview of Existing Concepts, Policies and Initiatives. Spain: European Union.

[15] Farquhar, C. (2020). [Online]. Knowledge Engineering in AI: Definition, Process \& Examples. [cited 26 March 2020]. Aavilable from: URL. https://study.com/academy/lesson/knowledge-engineering-in-ai-definition-process-examples.html\#lesson

[16] Anupan, A., Nilsook, P., and Wannapiroon, P. (2014). Designing Knowledge Engineering Approach to Enhance Knowledge Management System on Cloud Computing. The Fifth TCU International E-learning Conference 2014. August 5-6, 2014, Bangkok, Thailand: 65-89. https://doi.org/10.1109/tale.2016.7851826

[17] Thanachawengsakul, N., Wannapiroon, P., and Nilsook, P. (2019). Synthesis of Digital Knowledge Engineering Repository Management System. International Journal of e-Education, e-Business, e-Management and e-Learning, 9(4): 348-356.

[18] Hariyanto, D. (2020). A Web-Based Adaptive E-learning Application for Engineering Students: An Expert-Based Evaluation. International Journal of Engineering Pedagogy (iJEP), 10(2): 60-70. https://doi.org/10.3991/ijep.v10i2.11834

[19] Gamage, D., and Perera, I., and Fernando, S. (2020). MOOCs Lack Interactivity and Collaborativeness: Evaluating MOOC Platforms. International Journal of Engineering Pedagogy (iJEP), 10(2): 94-110. https://doi.org/10.3991/ijep.v10i2.11886

[20] Hanif, A., Siddiqi, A, F., and Jalil, Z. (2019). Are Computer Experience and Anxiety Irrelevant? Towards a Simple Model for Adoption of E-Learning Systems. International Journal of Engineering Pedagogy (iJEP), 9(5): 112-125. https://doi.org/10.3991/ijep.v9i5. $\underline{11488}$

\section{Authors}

Nattaphol Thanachawengsakul is currently working as an instructor for bachelor of education program in computer, Faculty of Science, Chandrakasem Rajabhat University, Bangkok, Thailand. He has expertise in system analysis and design, information and communication technology for education, digital knowledge engineering, knowledge management in education institutions, measurement and evaluation in education, educational management with the use of information and communication technology and research of information and communication technology for education. His Doctor of Philosophy in Information and Communication Technology was awarded a by King Mongkut's University of Technology North Bangkok (KMUTNB), Thailand.

Panita Wannapiroon is an associate professor at Division of Information and Communication Technology for Education, Faculty of Technical Education, King Mongkut's University of Technology North Bangkok (KMUTNB), Thailand. She has experience in many positions such as the director at Innovation and Technology Management Research Center, as assistant director of Online Learning Research Center, as assistant director of Vocational Education Technology Research Center, and an assistant director of Information and Communication Technology in Education Research Center. (e-Mail: panita.w@fte.kmutnb.ac.th)

Article submitted 2020-04-19. Resubmitted 2020-05-25. Final acceptance 2020-05-27. Final version published as submitted by the authors. 